\author{
E.P. Shevchuk ${ }^{1}$, D.K. Nurumkanov ${ }^{1}$, B.M. Muratbekov ${ }^{1}$, B. Ahmetzhanov ${ }^{1}$, V.A. Plotnikov ${ }^{2}$ \\ ${ }^{I}$ S. Amanzholov East Kazakhstan State University, Ust-Kamenogorsk, Kazakhstan; \\ ${ }^{2}$ Altay State University, Barnaul, Russia \\ (E-mail: evgeniya-shevchu@mail.ru)
}

\title{
Surface modification of steel 20 by the method of chemical-thermal treatment by annealing in a muffle furnace
}

\begin{abstract}
The article is devoted to the current problem related to the hardening of the surface layers of metal materials, including steel parts. The authors of the article describe the methods of chemical and thermal treatment of surface layers of materials to effectively improve the durability of machine parts and tools operating under various conditions of wear, at high temperature and force effects. The method of saturation of samples of iron plates by means of coating them with boron-containing mixtures in different volume proportions and their subsequent annealing in a muffle furnace is considered. The results of studies of the microhardness and thickness of the diffusion layer are given.
\end{abstract}

Keywords: steel 20, saturating mixture, boration, diffusion layer, microhardness, chemical-thermal treatment, muffle furnace.

\section{Introduction}

At the present stage of development of technology it is an urgent task of developing methods of strengthening the surface layers of metal materials, including steel parts with qualitatively new high properties that reduce the metal content of products and provide resource saving. Changing and complicating the operating conditions of machines, components and assemblies requires constant improvement of materials and modernization of manufacturing technologies.

Much attention is paid to the development of surface hardening technologies. This is due to a new approach to assessing the role of the material in ensuring the structural strength of products, according to which it is the state of the surface layers of materials largely determines the performance properties of parts.

Scientific and technical progress in such industries as engineering, transport, machine-tool industry and other high-tech sectors of the economy is largely associated with the improvement of the materials used in the direction of obtaining a set of performance properties.

Fundamentally new high physical, mechanical and operational properties of products can be achieved by purposeful modification of the surface by doping with various elements or their compositions using highly concentrated energy sources, including metallization, i.e. diffusion saturation of metals during furnace heating. The advantage of this method is the possibility of non-contact heating of the surface of the processed material. It is carried out at high temperatures (up to $1420^{\circ} \mathrm{C}$ ) while the thickness of the modified layer does not exceed 100 microns and the concentration of alloying elements in it, and therefore the hardness decreases sharply from the surface deep into the material.

Chemical-thermal treatment, changing the composition, structure, and, consequently, the properties of the surface layers of materials, is an effective way to increase the durability of machine parts and tools operating under different wear conditions, at high temperature and force effects $[1,2]$.

In this regard, relevant are: the study of processes occurring in the near-surface layer of carbon steels, when alloying using furnace heating. Development of new combined technologies that can not only significantly improve the physical, mechanical and operational properties of machine parts and tools by activating the maximum possible number of reinforcing mechanisms, but also to replace expensive alloy steel at a cheaper and affordable, to save energy and consumables, reduce the duration of processes and improve processing efficiency compared to traditional methods of hardening of structural and tool steels.

The aim of the work was to study the surface of ST20 after chemical and thermal treatment.

The use of the SNOL 30/1300 muffle laboratory furnace made it possible to ensure uniform and rapid heating of samples from $50^{\circ} \mathrm{C}$ to $1300^{\circ} \mathrm{C}$. 


\section{Research methods}

To study the kinetics of the growth of boride layers on the surface of the samples of iron plates, saturation was carried out with the help of coating and circular heating in the furnace. Boron paste contained a mixture of iron and boron powders in different volume proportions $\left(25 \% \mathrm{Fe}-75 \% \mathrm{H}_{3} \mathrm{BO}_{3}, 50 \% \mathrm{Fe}-50 \%\right.$ $\mathrm{H}_{3} \mathrm{BO}_{3}, 75 \% \mathrm{Fe}-25 \% \mathrm{H}_{3} \mathrm{BO}_{3}$ ), ammonium hydroxide, activated carbon and liquid glass [3; 387]. Previously, a similar coating composition was not applied when hardening the surface layers of steels of this class by boriding. What is a novelty in research?

Surface boration was carried out at a temperature of $\approx 1000{ }^{\circ} \mathrm{C}$ for 5 minutes.

Weight and volume of reagents: all data are obtained in accordance with the surface area of the treated surface of the iron plate.

Liquid glass $-\mathrm{Na}_{2} \mathrm{SiO}_{3}$ (concentrate) - $1 \mathrm{ml}$;

$20 \%$ p-p of liquid glass $-1 \mathrm{ml}$;

Ammonium hydroxide $-\mathrm{NH}_{4} \mathrm{OH}-1 \mathrm{ml}$.

Chemical processes in boration: liquid glass when mixed with a mixture of boric acid and iron powders forms a gel-like mass.

At a temperature of $50{ }^{\circ} \mathrm{C}$, the $\mathrm{NH} 4 \mathrm{OH}$ activator decomposes into ammonia in the form of gas and water $\left(\mathrm{NH}_{4} \mathrm{OH} \rightarrow \mathrm{NH}_{3} \uparrow+\mathrm{H}_{2} \mathrm{O} \rightarrow \mathrm{N} \uparrow+\mathrm{H}_{2} \mathrm{O} \uparrow+\mathrm{O}_{2} \uparrow\right)$, at $235^{\circ} \mathrm{C}$, boric acid decomposes into boron oxide and water $\left(2 \mathrm{H}_{3} \mathrm{BO}_{3} \rightarrow \mathrm{B}_{2} \mathrm{O}_{3}+3 \mathrm{H}_{2} \mathrm{O}\right)$. The introduction of an activator in the form of ammonium hydroxide and carbon into the coating makes it possible to ensure its reliable adhesion of the saturating charge to the hardened surface.

Boron oxide reacts with the coal and produces pure boron, and carbon monoxide $\left(2 \mathrm{~B}_{2} \mathrm{O}_{3}+3 \mathrm{C} \rightarrow 4 \mathrm{C}+\right.$ $+3 \mathrm{CO}_{2}$ ). In the temperature range from $500{ }^{\circ} \mathrm{C}$ to $1000{ }^{\circ} \mathrm{C}$ ammonia decomposes into nitrogen and hydrogen in the form of gas and acts as a boron carrier in the depth of the surface layer of the iron plate, forming a vast diffusion zone of iron borides. Water under high temperature is transferred into oxygen and hydrogen gas and evaporates $\left(2 \mathrm{H}_{3} \mathrm{BO}_{3}+2 \mathrm{Fe}+2 \mathrm{NH}_{4} \mathrm{OH}+2 \mathrm{C} \rightarrow \mathrm{Fe}_{2} \mathrm{~B}+\mathrm{IN}+2 \mathrm{~N} \uparrow+8 \mathrm{H}_{2} \uparrow+2 \mathrm{O}_{2} \uparrow+2 \mathrm{CO}_{2} \uparrow\right)$.

The released hydrogen acts as a boron carrier in the depth of the structure of the surface layer of the steel plate in the form of $\mathrm{B}_{10} \mathrm{H}_{14}$ [4].

The iron powder in the coating is partially oxidized by oxygen released during the interaction between the components of the coating, another part of the iron atoms diffuses into the surface of the samples in the form of separate iron borides.

The presence of iron powder in the coating helps to protect the active components of the coating from oxidation at high temperature heating.

Some iron particles in the process of high-temperature heating oxidized isolated during the interaction between the components of the oxygen coating, and part of them diffuses into the surface of the samples in the form of individual particles of iron and iron borides. Iron oxides remain in the scale zone and are removed during the preparation of samples for basic research by grinding.

Thermodynamically, iron borides are unstable, at $1650{ }^{\circ} \mathrm{C}$ they begin to decompose. The lower iron boride $\mathrm{Fe}_{2} \mathrm{~B}$ decomposes into iron and $\mathrm{FeB}: \mathrm{FeB} \rightarrow \mathrm{Fe}_{2} \mathrm{~B} \rightarrow(\alpha$-phase $+\mathrm{B}) \rightarrow$ base metal $[5 ; 427]$.

\section{Research result}

The analysis of the layers obtained on steel plates shows the dependence of the diffusion zone thickness on the volume content of boric acid in the mixtures of the initial powder.

The results of determination of microhardness:

$\mathrm{N}$ microhardness was determined on the device PMT-3 [6].

When the load on the indenter $\mathrm{P}=100 \mathrm{~g}(0.98 \mathrm{~N})$ and the holding time at this load 10 seconds. A regular four-sided diamond pyramid with an angle at the top of 1360 was used as an indenter for microhardness measurements, similar to the Vickers hardness test method. Microhardness of $\mathrm{H} \mu$ was determined in accordance with the requirements of GOST 9450-60 and the recommendations given in [7], using the formula (1):

$$
H_{\mu}=\frac{1854 P}{d_{\text {print }}{ }^{2}}\left[\mathrm{~kg} \cdot \mathrm{s} / \mathrm{mm}^{2}\right]=\frac{18,2 \cdot 10^{3}}{d_{\text {print }}{ }^{2}}\left[\mathrm{MN} / \mathrm{m}^{2}=\mathrm{MPa}\right],
$$

where the load is $\mathrm{P}(\mathrm{g})$, and the diagonal of the print $-d_{\text {print }}(\mu \mathrm{m})$.

Tests on the microhardness of the initial material ST20 were carried out. The microhardness of the starting material $\mathrm{H} \mu=2584 \mathrm{MPa}$, the microhardness of the material after thermal exposure is $\mathrm{H} \mu=2207 \mathrm{MPa}$. 
After the thermal effect on the coated samples, the microhardness of each of them was determined and compared with the initial data. Microhardness was determined from three positions: along the edge of the treated layer, horizontally and vertically.

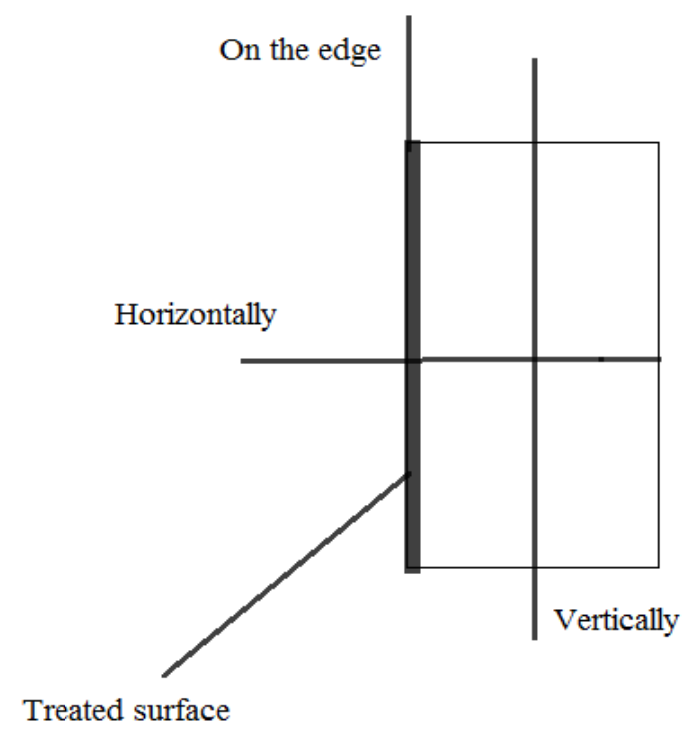

Figure 1. Direction of the measurement of microhardness

The microhardness of the first sample treated with a coating of $50 \% \mathrm{H}_{3} \mathrm{BO}_{3}$ and $50 \% \mathrm{Fe}$ was: horizontal $\mathrm{H} \mu=2144 \mathrm{MPa}$, vertical $\mathrm{H} \mu=2211 \mathrm{MPa}$, and on the edge $\mathrm{H} \mu=2202 \mathrm{MPa}$. There is no significant change from the original sample (Fig. 2).

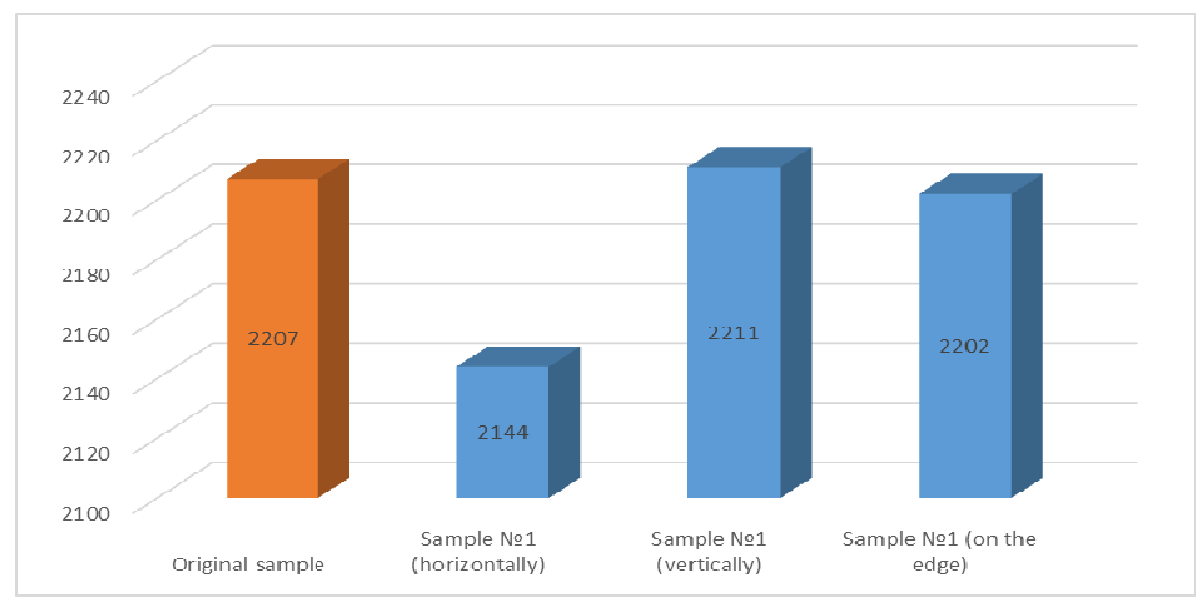

Figure 2. Microhardness of the treated sample $50 \% \mathrm{H}_{3} \mathrm{BO}_{3}$ and $50 \%$ Fe without liquid glass

The surface of the $2 \mathrm{nd}$ sample is treated with a mixture of $25 \% \mathrm{Fe}-75 \% \mathrm{H}_{3} \mathrm{BO}_{3}$ with $20 \%$ liquid glass solution. The microhardness of this sample was: horizontally $\mathrm{H} \mu=2373 \mathrm{MPa}$, vertically $\mathrm{H} \mu=2261 \mathrm{MPa}$, and at the edge $\mathrm{H} \mu=2409 \mathrm{MPa}$. Compared with the initial sample, no significant change was observed, the microhardness increased by $17 \%$ (Fig. 3). 


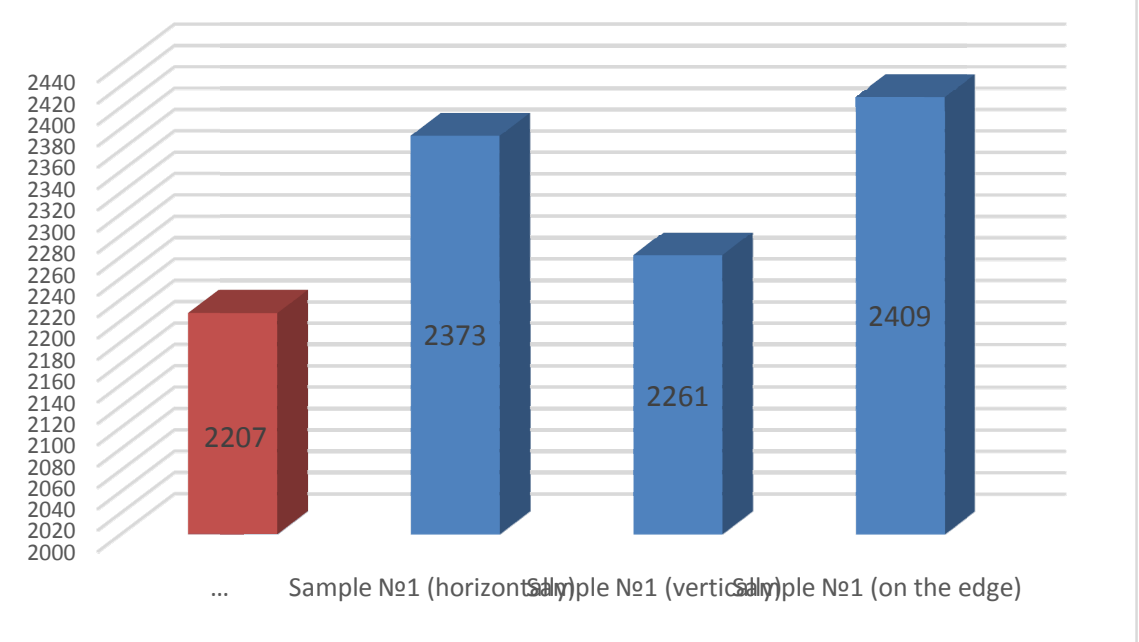

Figure 3. Microhardness of the treated sample $50 \% \mathrm{H}_{3} \mathrm{BO}_{3}$ and $50 \% \mathrm{Fe}$ with liquid glass

The surface of the third and fourth samples is treated with a mixture consisting of $75 \% \mathrm{H}_{3} \mathrm{BO}_{3}$ and $25 \% \mathrm{Fe}$ (by volume) and without $20 \%$ liquid glass solution, and without it, respectively.

Microhardness in samples treated with $75 \% \mathrm{H}_{3} \mathrm{BO}_{3}$ and $25 \% \mathrm{Fe}$ without liquid glass has increased significantly. Here, the microhardness of the sample was: horizontally $H \mu=2741 \mathrm{MPa}$, vertically $\mathrm{H} \mu=2647 \mathrm{MPa}$, and at the edge $\mathrm{H} \mu=2899 \mathrm{MPa}$. Compared with the original sample microhardness: horizontally increased by $20 \%$.

Microhardness of the surface layer of the sample treated with the same mixture, but with the addition of $20 \%$ solution of liquid glass showed the best results compared to the microhardness of the starting material and other processed samples. Here, the microhardness was: horizontally $\mathrm{H} \mu=2919 \mathrm{MPa}$, vertically $\mathrm{H} \mu=2642 \mathrm{MPa}$, and on the edge $\mathrm{H} \mu=2535 \mathrm{MPa}$. After this treatment, the horizontal microhardness increased by $25 \%$.

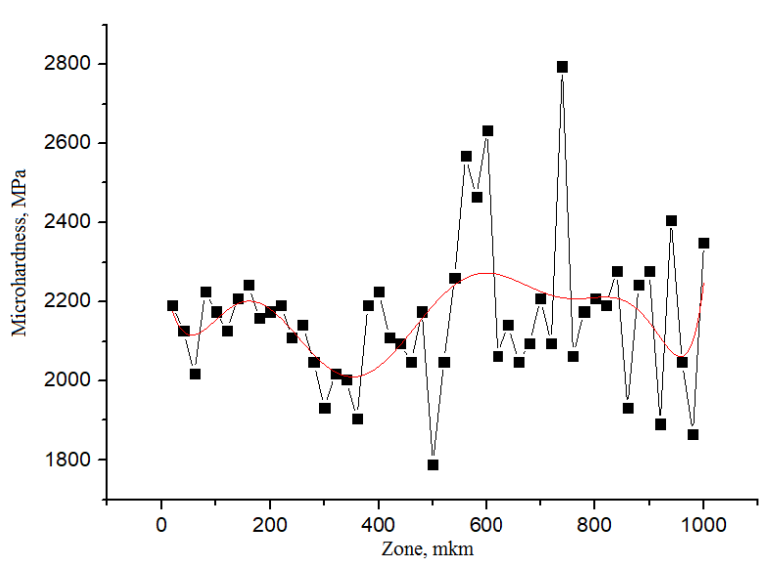

a

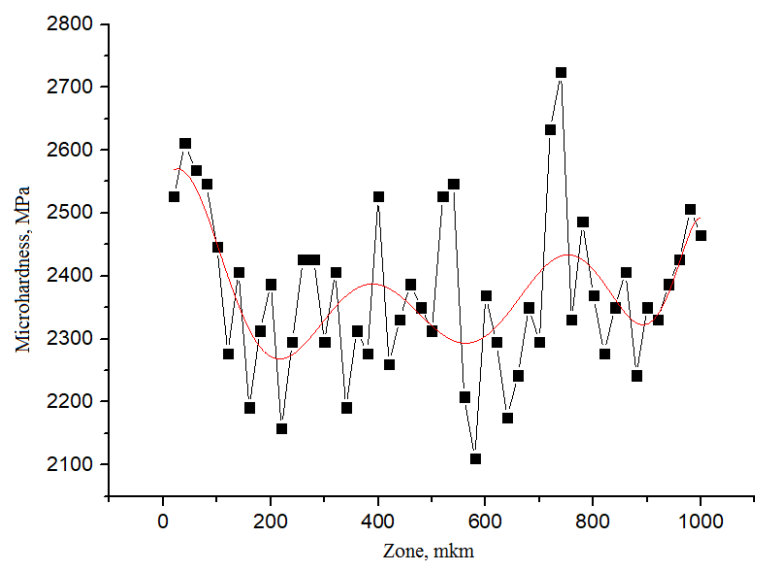

$\mathrm{b}$

Figure 4. Distribution of microhardness in the borated surface of steel 20 sample: $a$ - sample 1 and b-sample 2

From the data of Figure 4 on the distribution of microhardness in the cross section of samples 1 and 2, no significant change in microhardness compared to the microhardness of the substrate was revealed. 


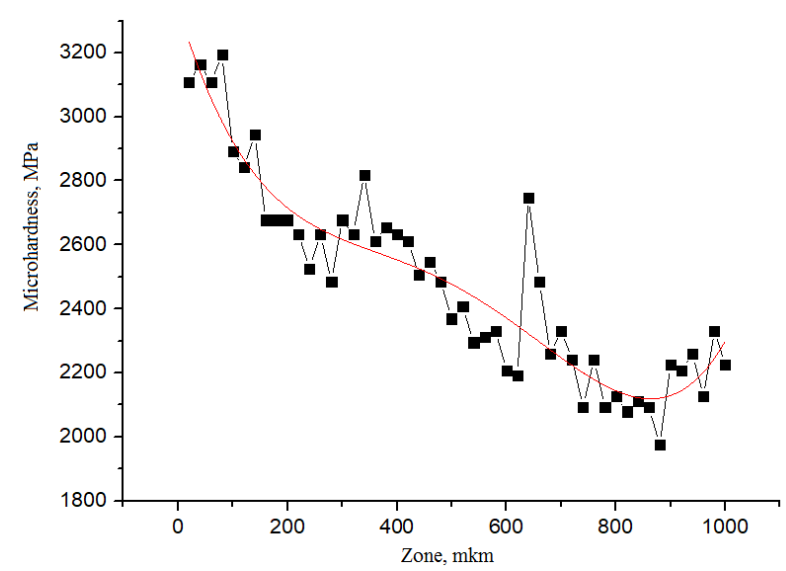

Figure 5. Distribution of microhardness in borated surface of steel 20 of sample 3

From Figure 5 it can be seen that the microhardness of the surface layer has increased significantly, and the diffusion distribution of boron in the diffusion zone is gradually reduced. At a depth of $595 \mu \mathrm{m}$, the microhardness of the test sample reaches the microhardness of the annealed substrate.

For most engineering calculations, there is a diffusion layer formula from the boration time [8].

$$
h^{2}=D \tau,
$$

where $\mathrm{h}$ is the thickness of the diffuse coating, $\mathrm{m}$; $\mathrm{D}$ is the diffusion coefficient, $\mathrm{m} / \mathrm{s}, \tau$ is the duration of the process, $\mathrm{s}$.

Hence, the diffusion coefficient is $\mathrm{D}=1.2 \cdot 10-9 \mathrm{~m}^{2} / \mathrm{s}$. This indicates an abnormally high mass transfer of boron, since it is orders of magnitude higher than the diffusion coefficient of boron at $9500{ }^{\circ} \mathrm{C}$, equal to $1.82 \cdot 10-11 \mathrm{~m}^{2} / \mathrm{s}[9]$.

X-ray structural analysis (Fig. 6, Table 1) showed the formation of two-phase $\alpha$-Fe compositions with a volume-centered cubic lattice and B with an orthorhombic cubic lattice. Sample 3 is in a three-phase state: $\alpha$ Fe with a bulk-centered cubic lattice, $\mathrm{B}$ with an orthorhombic cubic lattice, and $\mathrm{FeB}$ with a rhomboeder cubic lattice.

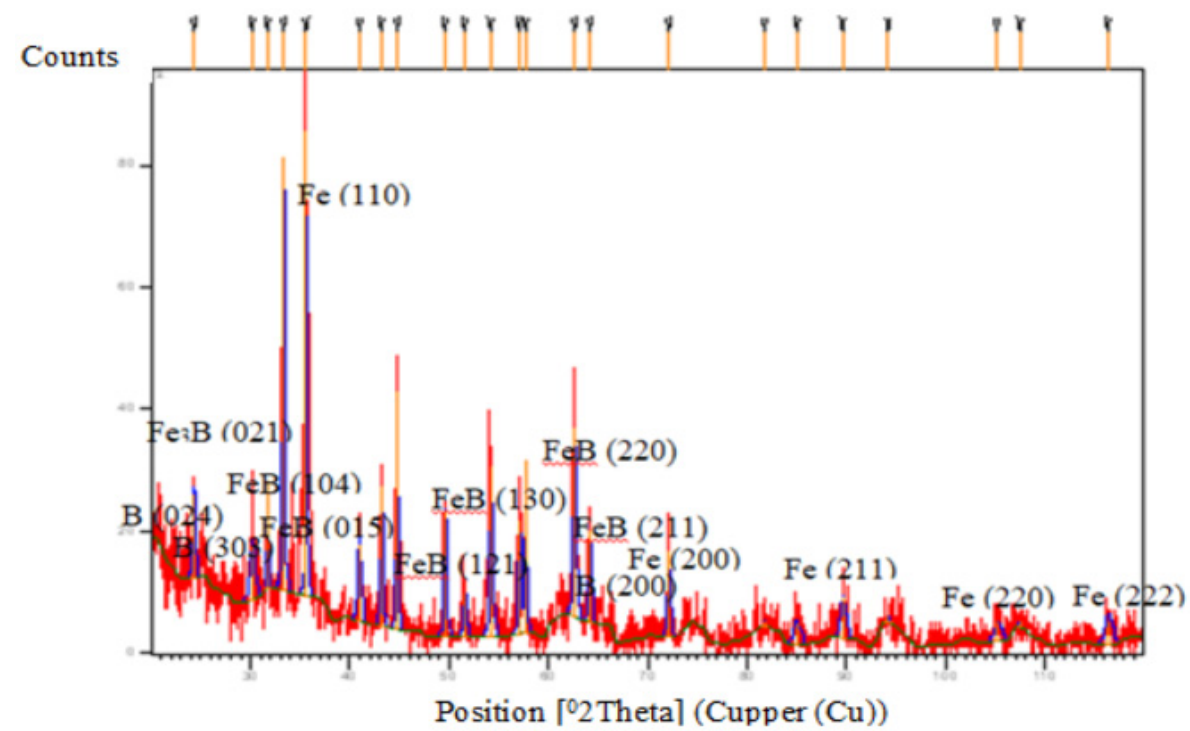

Figure 6. Structural phase state of sample 3 
State of the surface layer of sample 3

\begin{tabular}{|c|c|c|}
\hline Chemical element & hkl & Crystal lattice \\
\hline $\mathrm{B}$ & 024 & Rhombogedric \\
\hline $\mathrm{B}$ & 303 & Rhombogedric \\
\hline $\mathrm{Fe}_{3} \mathrm{~B}$ & 021 & Volume-centered cubic \\
\hline $\mathrm{FeB}$ & 104 & Orthorhombic \\
\hline $\mathrm{FeB}$ & 015 & Orthorhombic \\
\hline $\mathrm{Fe}$ & 110 & Cubic \\
\hline $\mathrm{FeB}$ & 121 & Orthorhombic \\
\hline $\mathrm{FeB}$ & 130 & Orthorhombic \\
\hline $\mathrm{FeB}$ & 220 & Orthorhombic \\
\hline $\mathrm{FeB}$ & 211 & Orthorhombic \\
\hline $\mathrm{B}$ & 200 & Rhombogedric \\
\hline $\mathrm{Fe}$ & 200 & Cubic \\
\hline $\mathrm{Fe}$ & 211 & Cubic \\
\hline $\mathrm{Fe}$ & 220 & Cubic \\
\hline $\mathrm{Fe}$ & 222 & Cubic \\
\hline
\end{tabular}

\section{Conclusion}

Analysis of the calculations of the microhardness of the surface layers of the samples after annealing in a muffle furnace at a temperature of $1000{ }^{\circ} \mathrm{C}$ for 5 minutes showed that the microhardness increased.

Microhardness in samples treated with $75 \% \mathrm{H}_{3} \mathrm{BO}_{3}$ and $25 \%$ Fe composition without liquid glass increased.

The experimental studies allow us to draw conclusions about the prospects of using this coating to produce iron borides on the surface layers of steel 20 . The use of various components of the mixture affects the change in microhardness, microstructure of the surface layer of steel 20.

According to the results of the diffusion layer and the diffusion coefficient, it can be assumed that the growth of the boride layer is abnormal.

Studies aimed at studying the comparison of the effects of various components of the paste, allow us to draw conclusions about the prospects of using this coating to obtain iron borides on its surface layers. The use of various components of the mixture also affects the change in the microhardness, microstructure of the surface layer of St20, as well as on the convenience of applying the coating and its cheapness.

\section{References}

1 Лахтин Ю.М. Химико-термическая обработка металлов: учеб. пос. / Ю.М. Лахтин, Б.Н. Арзамасов. - М.: Металлургия, $1985 .-256 \mathrm{c.}$

2 Ворошнин Л.Г. Борирование стали: учеб. пос. / Л.Г. Ворошнин, Л.С Ляхович. — М.: Металлургия, 1978. — 239 с.

3 Шевчук Е.П. Исследование боридных слоев стали 20 после химико-термической обработки в индукционной печи / Е.П. Шевчук, В.А. Плотников, Б.К. Ахметжанов // Фундаментальные проблемы современного материаловедения. - 2018. — T. 15, № 3. - С. 386-391.

4 Екимов Е.А. Получение микрокристаллов бора пиролизом декаборана $\mathrm{B}_{10} \mathrm{H}_{14}$ при высоких давлениях и температурах / Е.А. Екимов, И.П. Зибров, А.В. Зотеев // Неорганические материалы. — 2011. — Т. 47, № 11. — С. 1311-1316.

5 Шевчук Е.П. Формирование обширной диффузионной зоны при борировании стали 20 / Е.П. Шевчук, В.А. Плотников, А.В. Джес // Фундаментальные проблемы современного материаловедения. — 2018. — Т. 15, № 3. C. $424-428$.

6 Золоторевский В.С. Механические испытания и свойства металлов: учеб. / В.С. Золоторевский. - М.: Металлургия, 1974. - $304 \mathrm{c}$.

7 Харитонов Л.Г. Определение микротвердости: учеб. пос. / Л.Г. Харитонов. — М.: Металлургия, 1967. — 46 с.

8 Ворошнин Л.Г. Многокомпонентные диффузионные покрытия: учеб. пос. / Л.Г. Ворошнин. — Минск: Наука и техника, 1981. - 296 с.

9 Павлов П.В. Физика твердого тела: учеб. / П.В. Павлов, А.Ф. Хохлов. — М.: Высш. шк., 2000. — 494 с. 
Е.П. Шевчук, Д.К. Нурумканов, Б.М. Муратбеков, Б. Ахметжанов, В.А. Плотников

\title{
Муфельді пеште жану арқылы химиялық термиялық өндеу әдісімен 20 болаттың бетін модификациялау
}

\begin{abstract}
Мақала металл бөлшектердің, соның ішінде болат бөлшектерінің беткі қабаттарының беріктігін қатайтумен байланысты өзекті мәселеге арналған. Мақаланың авторлары жоғары температура әсеріндегі әртүрлі тозу жағдайында жұмыс істейтін машина бөлшектері мен құралдарының беріктігін арттыру үшін материалдардың беткі қабаттарының химиялық-термиялық өңдеу әдістерін сипаттайды. Темір пластиналардың үлгілерін әртүрлі көлемдегі пропорцияларда құрамында бор бар қоспалармен жабу арқылы және олардың кейінгі муфельдік пеште жағу әдісі қарастырылды. Диффузия қабатының микроқаттылығы мен қалыңдығын зерттеу нәтижелері көрсетілген.
\end{abstract}

Кілт сөздер: болат 20, қанықтыру қоспасы, бор қосу, диффузиялық қабат, микроқаттылық, химиятермиялық өңдеу, муфельдік пеш.

Е.П. Шевчук, Д.К. Нурумканов, Б.М. Муратбеков, Б. Ахметжанов, В.А. Плотников

\section{Модификация поверхности стали 20 методом химико-термической обработки путем отжига в муфельной печи}

\begin{abstract}
Статья посвящена актуальной на сегодняшний день проблеме, связанной с упрочнением поверхностных слоев металлических материалов, в том числе стальных деталей. Авторы описывают методы химико-термической обработки поверхностных слоев материалов для эффективного повышения долговечности деталей машин и инструментов, работающих в условиях различного износа, при высоких температурно-силовых воздействиях. Рассмотрен способ насыщения образцов железных пластинок с помощью обмазки их борсодержащими смесями в разных объемных пропорциях и последующим их отжигом в муфельной печи. Приведены результаты исследований микротвёрдости и толщины диффузионного слоя.
\end{abstract}

Ключевые слова: сталь 20, насыщающая смесь, борирование, диффузионный слой, микротвердость, химико-термическая обработка, муфельная печь.

\section{References}

1 Lakhtin, Yu.M., \& Arzamasov, B.N. (1985). Khimiko-termicheskaia obrabotka metallov [Chemical and thermal treatment of metals]. Moscow: Metallurhiia [in Russian].

2 Voroshnin, L.G., \& Lyakhovich L.S. (1978). Borirovanie stali [Steel boration]. Moscow: Metallurhiia [in Russian].

3 Shevchuk, E.P., Plotnikov, V.A., \& Akhmetzhanov, B.K. (2018). Issledovanie boridnykh sloev stali 20 posle khimikotermicheskoi obrabotki $v$ induktsionnoi pechi [Study of boride layers of steel 20 after chemical and thermal treatment in an induction furnace]. Fundamentalnye problemy sovremennoho materialovedeniia - Fundamental problems of modern materials science, 15, 3, 386-391 [in Russian].

4 Ekimov, E.A., Zibrov I.P., \& Zoteyev, A.V. (2011). Poluchenie mikrokristallov bora pirolizom dekaborana $\mathrm{B}_{10} \mathrm{H}_{14}$ pri vysokikh davleniiakh i temperaturakh [Obtaining of boron microcrystals by decemborane pyrolysis $\mathrm{B}_{10} \mathrm{H}_{14}$ at high pressures and temperatures]. Neorhanicheskie materialy - Inorganic materials, 47.11, 1311-1316 [in Russian].

5 Shevchuk, E.P., Plotnikov, V.A., \& Dzhes, A.V. (2018). Formirovanie obshirnoi diffuzionnoi zony pri borirovanii stali 20 [Formation of a large diffusion zone in steel boration 20]. Fundamentalnye problemy sovremennoho materialovedeniia - Fundamental problems of modern materials science, 15, 3, 424-428 [in Russian].

6 Zolotorevskiy, V.S. (1974). Mekhanicheskie ispytaniia i svoistva metallov [Mechanical tests and properties of metals]. Moscow: Metallurhiia [in Russian].

7 Kharitonov, L.G. (1967). Opredelenie mikrotverdosti [Determination of microhardness]. Moscow: Metallurhiia [in Russian].

8 Voroshnin, L.G. (1981). Mnohokomponentnye diffuzionnye pokrytiia [Multicomponent diffusion coatings]. Minsk: Nauka i tekhnika [in Russian].

9 Pavlov, P.V., \& Khokhlov, A.F. (2000). Fizika tverdoho tela [Physics of the solid state]. Moscow: Vysshaia shkola [in Russian]. 